\title{
Pengaruh Penambahan Gas HHO pada Mesin Bensin Terhadap Emisi dan Konsumsi Bahan Bakar
}

\author{
Ajat Sudrajat $^{1 *}$, Irfan Nugroho', Kiki Rezki Lestari ${ }^{1}$, V. Vekky Ronald Repi ${ }^{1}$ \\ ${ }^{1}$ Program Studi Teknik Fisika, Universitas Nasional JL. Sawo Manila, Pejaten, Pasar Minggu, \\ Jakarta 12520. \\ *Korespondensi penulis: ajatsudrajatr2@yahoo.com
}

\begin{abstract}
Abstrak. Gas HHO merupakan suplemen bahan bakar yang dihasilkan dari proses elektrolisa air pada sebuah generator HHO, dimana gas HHO termasuk energi alternatif yang tergolong energi baru. Prinsip kerja mesin pembakaran internal, pada umumnya, adalah mengubah energi kimia dari bahan bakar cair menjadi energi mekanik. Produksi hidrogen melalui proses elektrolisis terus dikembangkan untuk membantu penggunaan bahan bakar ramah lingkungan dan dapat berdampak pada kinerja mesin dan emisi gas buang. Penelitian ini tentang pengaruh penambahan gas hho pada mesin bensin electronic fuel injection (EFI) type-L terhadap emisi gas buang dan konsumsi bahan bakar. Terbukti bahwa penambahan gas HHO pada proses pembakaran mesin bensin dengan sistem EFI khususnya tipe D memberikan hasil penurunan kadar emisi (CO $15.31 \%$ dan HC $16.27 \%$ ). Dan selanjutnya dengan menambahkan gas HHO 0.1 Mol pada mesin EFI tipe L melalui filter udara didapatkan pengaruh emisi gas buang yang signifikan dan konsumsi bahan bakar yang lebih boros $2.8 \%$ daripada tanpa menggunakan gas $\mathrm{HHO}$, hal tersebut dapat dimungkin karena mesin dengan sistem EFI memiliki karakteristik berbeda dengan mesin pada umumnya dan tidak mengenal suplemen bahan bakar yang diinjeksikan kedalam mesin.
\end{abstract}

Kata Kunci: Gas HHO, generator HHO, mesin bensin, emisi gas buang, konsumsi bahan bakar.

\section{PENDAHULUAN}

Kondisi perubahan iklim karena pemanasan global yang salah satunya disebabkan oleh pembakaran pada motor bakar yang tidak sempurna [1]. Gas yang keluar dari hasil pembakaran motor bakar mengandung unsur-unsur seperti karbon monoksida (CO), oksida sulfur (SOx) dan oksida nitrogen (NOx), yang berbahaya bagi kesehatan serta dapat merusak lingkungan [2]. Pada motor bakar bensin dan diesel memiliki hasil pembakaran yang berbeda-beda, salah satunya pada pada mesin bensin pada umumnya tidak terlihat tetapi lebih berbahaya karena terdapat unsur $\mathrm{CO}, \mathrm{HC}$ dan $\mathrm{Pb}$. Upaya mengurangi kadar emisi gas buang tersebut salah satunya adalah dengan mensubstitusi bahan bakar fosil dengan energi alternatif [3]. Energi alternatif salah satunya adalah hidrogen, karena memiliki beberapa keunggulan yaitu tidak menyebabkan polusi karbon. Metode yang dapat digunakan untuk memadukan penggunaan hidrogen dengan bahan bakar adalah penambahan gas tersebut pada proses pembakaran mesin. Produksi gas hidrogen salah satunya dapat menggunakan metode elektrolisis air. Produk gas hidrogen yang dihasilkan melalui elektrolisis air adalah gas HHO. Gas HHO merupakan campuran gas hidrogen dengan oksigen yang diproduksi dari elektrolisis air (H2O). Karena proses pembakaran pada mesin berlangsung terus menerus, berarti dibutuhkan juga gas HHO yang siap digunakan selama pembakaran. Sehingga dibutuhkan sistem pembangkit (generator) yang dapat menyuplai gas HHO secara kontinyu [3].

Penambahan gas HHO pada proses pembakaran mesin bensin dengan sistem EFI khususnya tipe D menarik perhatian karena beberapa penelitian memberikan hasil penurunan kadar emisi dan konsumsi bahan bakar yang baik. Iqbal wahyudin dan Laksana Guntur melakukan penelitian penambahan gas HHO pada mesin EFI tipe D dan didapatkan 
penurunan $\mathrm{CO} 15.31 \%$ dan $\mathrm{HC}$ menurun $16.27 \%$ pada putaran mesin $3000 \mathrm{rpm}$ [4]. Yasin Karagöz dkk mendapatkan hasil penurunan $\mathrm{HC} 5.55 \%$ dan CO $3.57 \%$ pada putaran mesin $2500 \mathrm{rpm}$ [5]. Pada mesin bensin khususnya sistem EFI tipe L belumnya ada penelitian seberapa pengaruh emisi dan konsumsi bahan bakar akibat penambahan gas HHO karena hal tersebut diperlukan penelitian untuk mengetahui pengaruhnya.

\section{TINJAUAN LITERATUR}

\section{Emisi Gas Buang}

Proses pembakaran motor bensin yang terdiri atas unsur bensin (Heptane $\mathrm{C} 7 \mathrm{H} 16$ dan Iso Oktana $\mathrm{C} 8 \mathrm{H} 18)$ dengan udara (O2, N2, dan unsur yang lain) akan menghasilkan emisi gas buang yang meliputi hidrokarbon (HC), karbon monoksida $(\mathrm{CO})$, karbon dioksida $(\mathrm{CO} 2)$, oksida nitrogen (NOx), timah hitam tetra ethyl lead $(\mathrm{Pb})$, dan sulfur atau belerang ( $\mathrm{SO} 2)$ serta bahan partikulat yang lainnya [2].

Hidrokarbon (HC) merupakan unsur senyawa bahan bakar bensin, jadi setiap HC yang didapat di gas buang kendaraan menunjukkan adanya bensin yang tidak terbakar dan terbuang bersama sisa pembakaran. Apabila suatu senyawa hidrokarbon terbakar sempurna (bereaksi dengan oksigen) maka hasil reaksi pembakaran tersebut adalah karbondioksida (CO2) dan air (H2O). Walaupun rasio perbandingan antara udara dan bensin atau air to fuel ratio (AFR) sudah tepat dan didukung oleh desain ruang bakar mesin saat ini yang sudah mendekati ideal, tetapi tetap saja sebagian dari bensin seolah-olah tetap dapat bersembunyi dari api saat terjadi proses pembakaran dan menyebabkan emisi HC pada ujung knalpot cukup tinggi. Kendaraan roda 4 yang tidak dilengkapi dengan catalytic converter (CC), emisi $\mathrm{HC}$ yang dapat ditolerir adalah $500 \mathrm{ppm}$ dan untuk mobil yang dilengkapi dengan $\mathrm{CC}$, emisi $\mathrm{HC}$ yang dapat ditolerir adalah $50 \mathrm{ppm}[6]$.

Karbonmonoksida (CO) merupakan senyawa gas yang terbentuk akibat pembakaran yang tidak sempurna dalam proses kerja motor bakar, gas $\mathrm{CO}$ merupakan gas yang relatif tidak stabil dan cenderung bereaksi dengan unsur lain, $\mathrm{CO}$ dapat diubah dengan mudah menjadi karbon dioksida $\left(\mathrm{CO}_{2}\right)$ dengan bantuan sedikit oksigen dan panas, $\mathrm{CO}$ diukur dalam satuan $\%$ pervolume atau dalam ppm [7]. Kadar CO yang besar diakibatkan oleh perbandingan campuran antara bahan bakar bensin dan udara tidak sesuai, dimana kandungan bensin terlalu banyak, tetapi disini walaupun kandungan bahan bakar bensin terlalu banyak tetapi masih dapat terbakar sehingga menghasilkan emisi $\mathrm{CO}$ yang besar, $\mathrm{CO}$ besar dapat disebabkan oleh kesalahan dalam penyetelan karburator sehingga homogenitas campuran menjadi jelek, filter udara yang kotor juga akan mengurangi jumlah udara yang masuk kedalam ruang bakar [8].

Konsentrasi $\mathrm{CO}_{2}$ menunjukkan secara langsung status proses pembakaran di ruang bakar. Semakin tinggi maka semakin baik. Saat AFR berada di angka ideal, emisi CO2 berkisar antara $12 \%$ sampai $15 \%$. Apabila AFR terlalu kurus atau terlalu kaya, maka emisi $\mathrm{CO} 2$ akan turun secara drastis. Apabila $\mathrm{CO} 2$ berada dibawah $12 \%$, maka kita harus melihat emisi lainnya yang menunjukkan apakah AFR fuel-rich-mixture atau fuel- lean-mixture. Perlu diketahui bahwa sumber dari $\mathrm{CO}_{2}$ ini hanya diruang bakar. Apabila $\mathrm{CO}_{2}$ terlalu rendah tapi $\mathrm{CO}$ dan $\mathrm{HC}$ normal, menunjukkan adanya kebocoran exhaust pipe [9].

Konsentrasi oksigen di gas buang adalah sekitar $1.2 \%$ atau lebih kecil bahkan mungkin $0 \%$, apabila konsentrasi oksigen mencapai $0 \%$. Ini menunjukkan bahwa semua oksigen dapat terpakai semua dalam proses pembakaran dan ini dapat berarti bahwa AFR cenderung pada keadaan campuran bahan bakar berlebih. Dalam kondisi demikian, rendahnya konsentrasi oksigen akan berbarengan dengan tingginya emisi CO. Konsentrasi oksigen tinggi dapat berarti AFR pada keadaan campuran sedikit bahan bakar tapi juga dapat menunjukkan beberapa hal lain dan tingginya $\mathrm{CO}$ dan $\mathrm{HC}$ bila oksigen terlalu tinggi dan lainnya rendah berarti ada kebocoran di exhaust sistem [2].

Beberapa keadaan pembakaran bisa juga dalam keadaan fuel-lean mixtures atau fuel-rich mixtures. Keadaan fuel-lean mixtures adalah rasio antara udara dan bahan bakar tidak 
seimbang karena campuran bahan bakar sedikit, fuel-rich mixtures adalah rasio antara udara dan bahan bakar tidak seimbang karena campuran bahan bakar berlebih, dan stoichiometric mixtures adalah rasio antara udara dan bahan kabar dalam kondisi sempurna atau tepat. Maka air fuel ratio relative $(\lambda)$ dijelaskan pada persamaan dibawah [10].

Komposisi produk tidak dapat ditentukan dari unsur keseimbangan saja dan asumsi tambahan tentang komposisi kimia dari spesies produk harus dibuat. Karena komposisi produk pembakaran berbeda secara signifikan untuk campuran bahan bakar yang sedikit dan banyak bahan bakar, dan karena air fuel ratio stoichiometric bergantung pada komposisi bahan bakar, air fuel ratio aktual terhadap rasio stoichiometric (atau yang Invers) adalah parameter yang lebih informatif untuk menentukan komposisi campuran. Nilai berarti fuel- lean mixtures, berarti stoichiometric mixtures dan berarti fuel-rich [11].

Dalam realitasnya bahan bakar bensin tidaklah murni, tetapi merupakan senyawa dari beberapa hydrocarbon, sehingga nilai AFR-nya pada pembakaran sempurna adalah bergerak antara 14:1 sampai 15:1, secara praktis, AFR ideal adalah 14.7:1 atau senilai dengan lambda $(\lambda)=1$, yang diperoleh dariperbandingan antara AFR real dibanding AFR teoritis [12].

\section{Gas HHO}

Hidrogen adalah salah satu unsur yang paling banyak ditemukan, dari masa semua materi yang ada di alam semesta terbentuk dari hidrogen. Hidrogen yang memiliki atom dengan satu elektron yang mengorbit mengelilingi intinya. Hidrogen berubah menjadi cair pada suhu $20 \mathrm{~K}\left(-423^{\circ} \mathrm{F} ;-253^{\circ} \mathrm{C}\right)$ [11]. Bahan bakar akan menghasilkan sejumlah energi pada saat bereaksi sepenuhnya dengan oksigen. Kandungan energi pada beberapa bahan bakar dapat dilihat pada tabel 1 .

TABEL 1. Nilai Kalor Dari Beberapa Bahan Bakar [10].

\begin{tabular}{ccc}
\hline Bahan Bakar & $\begin{array}{c}\text { Nilai pemanasan tertinggi } \\
\left(\mathbf{2 5}^{\circ} \mathbf{c} \text { dan } \mathbf{~ a t m}\right)\end{array}$ & $\begin{array}{c}\text { Nilai pemanasan terendah } \\
\text { (25'c dan } \mathbf{~ a t m})\end{array}$ \\
\hline Hidtogen & $121.86 \mathrm{MJ} / \mathrm{kG}$ & $119.93 \mathrm{MJ} / \mathrm{kG}$ \\
Metana & $55.53 \mathrm{MJ} / \mathrm{kG}$ & $50.02 \mathrm{MJ} / \mathrm{kG}$ \\
Propana & $50.36 \mathrm{MJ} / \mathrm{kG}$ & $45.6 \mathrm{MJ} / \mathrm{kG}$ \\
Bensin & $47.5 \mathrm{MJ} / \mathrm{kG}$ & $44.5 \mathrm{MJ} / \mathrm{kG}$ \\
Diesel & $44.8 \mathrm{MJ} / \mathrm{kG}$ & $42.5 \mathrm{MJ} / \mathrm{kG}$ \\
Metanol & $19.96 \mathrm{MJ} / \mathrm{kG}$ & $18.05 \mathrm{MJ} / \mathrm{kG}$ \\
\hline
\end{tabular}

Gas HHO atau Brown's gas adalah gas yang dihasilkan elektrolisis air yang merupakan kombinasi dari dua gas hidrogen $(\mathrm{H} 2)$ dan oksigen $(\mathrm{O} 2)$. Persamaan sederhana konversi air menjadi HHO dapat ditulis sebagai berikut :

$$
\mathrm{H} 2 \mathrm{O}(\mathrm{l}) \rightarrow \mathrm{HHO}(\mathrm{g})
$$

Sel elektrolisis yang dihubungkan dengan arus listrik akan memisahkan air menjadi hidrogen dan oksigen :

$$
2 \mathrm{H} 2 \mathrm{O}+\text { energi } \rightarrow 2 \mathrm{H} 2+\mathrm{O} 2
$$

Proses elektrolisis dapat dipercepat dengan bantuan katalis dan selama proses berjalan, katalis tidak mempengaruhi bentuk hasil elektrolisis tersebut. Katalis bertujuan untuk mempercepat reaksi elektrolisis dan menurunkan jumlah energi aktivasi yang dibutuhkan dalam suatu proses.

$$
2 \mathrm{H} 2 \mathrm{O}+\text { katalis }+ \text { energi } \rightarrow 2 \mathrm{H} 2+\mathrm{O} 2+\text { katalis }
$$

Sehingga reaksi kimia yang terjadi pada elektrolisis adalah [13] :

$$
2 \mathrm{H} 2 \mathrm{O} \rightarrow 2 \mathrm{H} 2+\mathrm{O} 2
$$

\section{Elektrolisis}

Elektrolisis merupakan proses kimia yang mengubah energi listrik (arus listrik) menjadi energi kimia (reaksi redoks). Elektrolisis adalah proses penguraian unsur-unsur pembentuk 
air. Dengan menggunakan arus listrik, dua molekul air bereaksi dengan menangkap dua elektron pada katoda yang tereduksi menjadi gas $\mathrm{H}_{2}$ dan ion hidroksida $(\mathrm{H})$. Pada kutub anoda, dua molekul air lainya akan terurai menjadi gas oksigen $\left(\mathrm{O}_{2}\right)$ dangan melepaskan 4 ion $\mathrm{H}+$ serta mengalirkan elektron ke katoda. Akibat reaksi tersebut, ion $\mathrm{H}+\mathrm{dan} \mathrm{OH}-$ akan mengalami netralisasi dan membentuk molekul air kembali. Gas hidrogen dan oksigen yang dihasilkan oleh reaksi tersebut membentuk gelembung dan mengumpul disekitar elektroda. Prinsip ini kemudian dimanfaatkan untuk menghasilkan hidrogen dan hidrogen peroksida ( $\mathrm{H} 2 \mathrm{O} 2)$.

Komponen-komponen terpenting dari proses elektrolisis ini adalah elektroda dan larutan elektrolit. Pada proses elektrolisis diperlukan dua buah kutub, yaitu katoda sebagai kutub negatif dan anoda sebagai kutub positif [12]. Proses elektrolisa terjadi dalam sebuah chamber yang dibuat secara khusus, dinamakan generator $\mathrm{HHO}$ yaitu sebuah pembangkit gas HHO. Generator HHO diklasifikasikan menjadi 2 tipe, yakni generator HHO tipe kering (dry cell) dan tipe basah (wet cell). Tipe kering, elektrodanya tidak terendam elektrolit dan elektrolit hanya mengisi celah-celah antara elektroda itu sendiri. Luasan lingkaran pada plat elektroda yang terendam air adalah area terjadinya elektrolisis untuk menghasilkan gas HHO, sedangkan bagian luasan yang lainnya tidak terendam air dan plat dalam kondisi kering. Tipe basah, generator HHO dimana semua elektrodanya terendam cairan elektrolit di dalam sebuah bejana air [13].

\section{Katalis}

Katalis didefinisikan sebagai suatu zat yang mempercepat laju reaksi namun katalis tersebut tidak mengalami perubahan kimia. Katalis tidak ditulis dalam persamaan reaksi stoikiometri dan konsentrasinya dalam campuran reaksi tidak berubah. Hal ini hanya mungkin jika pada satu tahap reaksi yang katalisnya ikut bereaksi dan tahap yang lainya itu dihasilkan kembali. Oleh karena itu katalis tidak terdapat pada persamaan reaksi, dan konsentrasinya pun tidak terdapat dalam ungkapan kesetimbangan. Dengan demikian katalis tidak mempengaruhi kedudukan kesetimbangan reaksi. Secara umum katalis akan menurunkan besarnya energi pengaktifan [14].

Katalis pada proses elektrolisis adalah katalisator yang dilarutkan didalam air $(\mathrm{H} 2 \mathrm{O})$ dan menyatu membentuk larutan elektrolit. Katalis yang biasa digunakan pada proses elektrolisis yaitu diantaranya garam cuka $(\mathrm{H} 3 \mathrm{C}-\mathrm{COOH})$, soda kue $(\mathrm{NaHCO})$ dan kalium hidroksida (KOH). Semakin sedikit jumlah katalis, laju produksi gas HHO menjadi sedikit. Sebaliknya, jika katalis yang digunakan terlalu banyak, akan menaikan suhu pada prosesnya [16]. Umumya proses elektrolisis untuk menghasilkan gas HHO menggunakan katalis $\mathrm{KOH}$ dan $\mathrm{NaHCO}$, penggunaan katalis katalis $\mathrm{KOH}$ pada proses elektrolisis lebih baik daripada katalis $\mathrm{NaHCO} 3$ karena dapat menghasilkan gas HHO lebih besar dan konsumsi daya listrik yang lebih rendah. Perhitungan konsentrasi katalis dengan pelarut dan menggunakan rumus molaritas sebagai berikut [15] :

$$
\mathrm{Jk}=\mathrm{Mr} \times \mathrm{M} \times 1 \mathrm{~mol} / \mathrm{liter}(\text { gram })
$$

Dimana:

$\mathrm{Jk}=$ Jumlah katalis (gram) $\mathrm{M}=$ Molaritas

$\mathrm{Mr}=$ Masa atom relatif

\section{METODOLOGI PENELITIAN}

Proses penelitian penambahan gas $\mathrm{HHO}$ pada mesin didahuui oleh perancangan dan pembuatan generator $\mathrm{HHO}$, kalibrasi dan pengujian generator HHO. Setelah dilakukan kalibrasi dan individual test terhadap generator HHO, langkah selanjutnya instalasi generator HHO pada mesin kendaraan untuk melakukan uji emisi dan uji penggunaan komsumsi bahan bakar minya. Secara garis besar tahapan penelitian dapat dilihat pada gambar 4. 


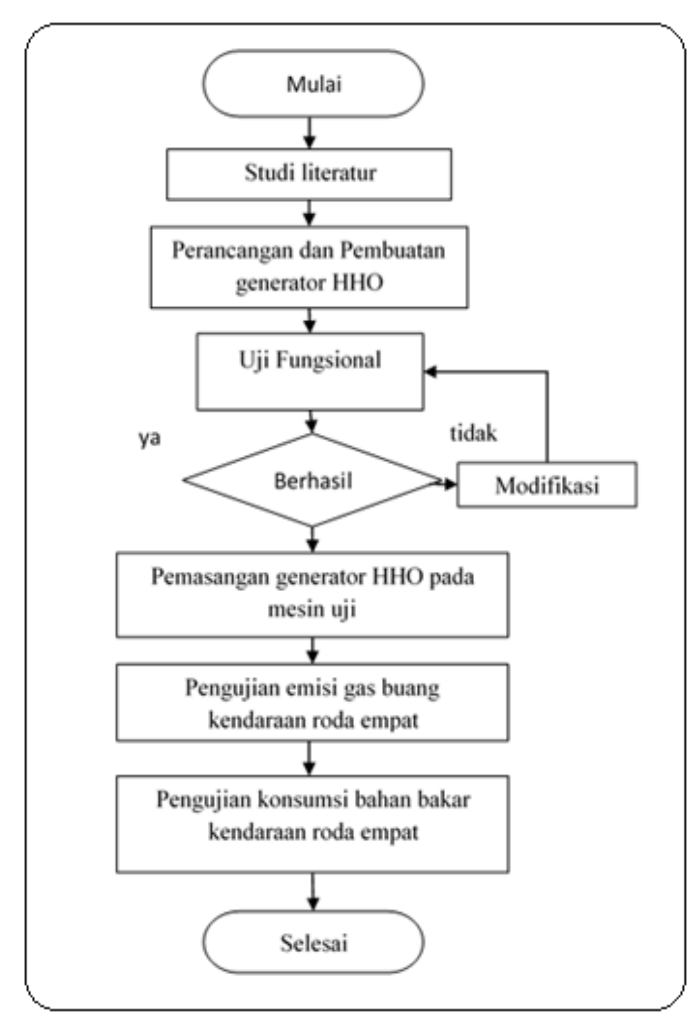

GAMBAR 1. Proses metodologi penelitian.

Dalam penelitian ini digunakan beberapa peralatan baik berupa barang inventarisir, benda uji dengan tipe mesin 4 silinder segaris, 16 katup DOHC, VVT-i/IL 4 silinder. Isi silinder $1.497 \mathrm{cc}$ dengan diameter langkah $75 \times 84.7(\mathrm{~mm} \times \mathrm{mm})$, daya maksimum 109/6000 (ps/rpm). Torsi maksimum 14.4/4200 (kgm/rpm, kapasitas tangka 42 lt dengan tipe sistem injeksi elektronik.

\section{Perancangan dan Pembuatan Generator HHO}

Sel elektrolisis dengan casing generator ukuran $25 \mathrm{~cm} \times 30 \mathrm{~cm}$. Plat yang digunakan adalah stainless steel 316L. Konfigurasi plat menggunakan 2 plat anoda dan katoda ukuran $9 \mathrm{~m}$ $14.5 \mathrm{~cm}$ beserta penutup dan plat netral ukuran $3 \mathrm{~cm} \times 14.5 \mathrm{~cm}$ ukuran tersebut didesain kebutuhan arus pada baterai aki kendaraan roda empat, ampere tidak melebihi dari total ampere yaitu 15 Amp. Pada sel reaktor plat netral disusun secara vertikal dengan jumah 3 plat dan diberi pembatas antar pelapis jarak $1 \mathrm{~mm}$ per $1 \mathrm{sel}$, agar terdapat ruang pemisah dalam proses elektrolisis terdapat pada gambar 2 .

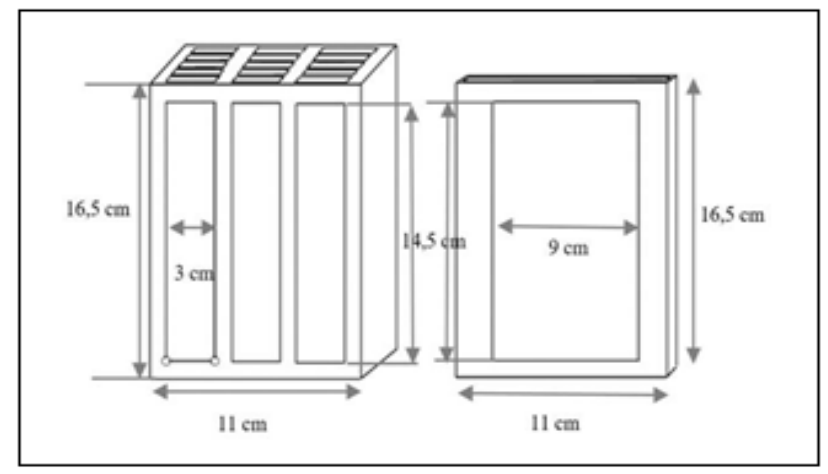

GAMBAR 2. Tampak desain pemisah penutup HHO.

\section{Uji Fungsional}

Uji fungsional generator HHO dilakukan untuk mengetahui apakah generator yang dibuat dapat bekerja sesuai dengan yang diharapkan dan tidak ada kebocoran gas. Uji fungsional 
dilakukan dengan cara mengalirkan arus listrik pada generator gas HHO dari battere $a c c u$ dan menggunakan katalis $\mathrm{KOH}$ dengan konsentrasi larutan 0.1.
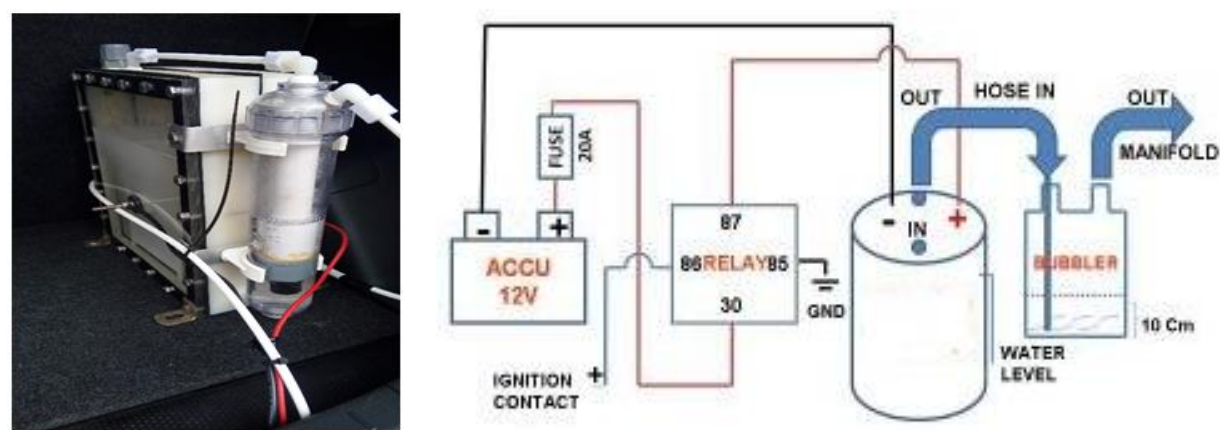

GAMBAR 3. Skematik diagram instalasi generator HHO.

Generator tersebut terpasangan dengan skema pemasangan terdapat pada gambar 3. Selang keluarannya gas HHO dan kabel positif yang terhubung ke relay dan bateray aki dilapisi kabel protector agar terlindung dari panas mesin.

\section{Pengujian Emisi Gas Buang dan Konsumsi bahan bakar}

Tahapan pengujian tanpa penambahan gas HHO dan tahapan dengan penambahan gas HHO. Pengujian dilakukan pada rpm idle, rpm 1500 dan rpm 2500. Pengujian konsumsi bahan bakar dilakukan dengan dua tahapan, tahapan pengujian bahan bakar bensin dan tahapan dengan penambahan gas HHO. Pengujian dilakukan saat bensin terisi penuh dan kendaraan menempuh jarak tertentu dengan pengabilan data sebanyak tiga kali.

\section{HASIL DAN PEMBAHASAN}

\section{Analisa dan Pembahasan Data Emisi Gas Buang}

Pada bagian ini menampilkan hail penelitian dan pembahasan yang meliputi antara lain, karbon monoksida, hidrokarbon, karbon dioksida, oksigen dan air fuel rasio dari proses pembakaran pada mesin pembakaran dalam (internal combustion engine) atau IC.

Karbon monoksida, merupakan gas yang tak berwarna, tak berbau, dan tak berasa, yang dihasilkan dari pembakaran tak sempurna dari senyawa karbon, sering terjadi pada mesin pembakaran dalam. Karbon monoksida terbentuk apabila terdapat kekurangan oksigen dalam proses pembakaran, dan bersifat mudah terbakar dan menghasilkan lidah api berwarna biru, menghasilkan karbon dioksida.

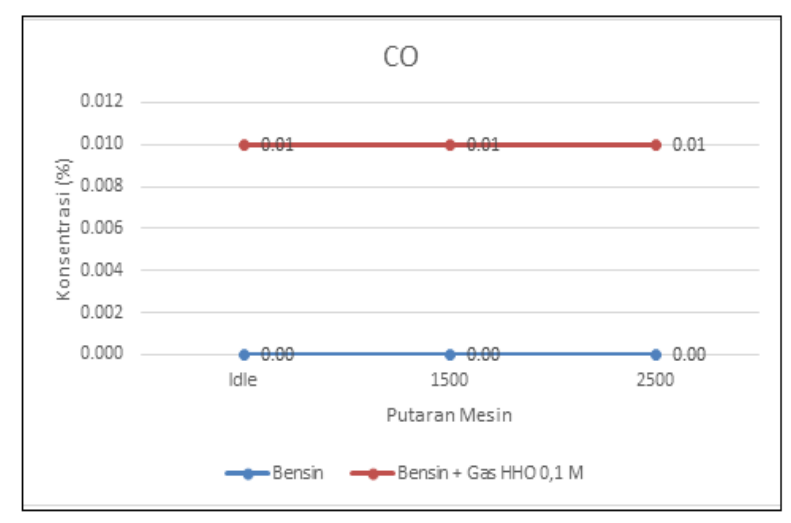

GAMBAR 4. Grafik hasil emisi gas buang karbon monoksida.

Pada gambar 4 menunjukkan grafik hasil kadar emisi CO tanpa menggunakan bahan bakar bensin pada putaran mesin idle adalah $0.00 \%$, putaran mesin $1500 \mathrm{rpm}$ adalah $0.00 \%$, dan putaran mesin adalah $2500 \mathrm{rpm}$ adalah $0.00 \%$. Penambahan gas HHO 0.1 Mol didapatkan data tersebut pada putaran mesin idle adalah $0.01 \%$, putaran mesin $1500 \mathrm{rpm}$ adalah 0,01 
$\%$, dan putaran mesin $2500 \mathrm{rpm}$ adalah $0.01 \%$. Kadar CO yang besar pada umunya diakibatkan oleh perbandingan campuran antara bahan bakar bensin dan udara tidak sesuai, dimana kandungan bahan bakar bensin terlalu banyak. Pada mesin injeksi khususnya tipe L bahan bakar bensin diinjeksikan pada ruang pembakaran tergantung pada sensor airflow yang mendeteksi jumlah udara pada filter udara. Penambahan gas HHO menyebabkan bahan bakar lebih banyak diinjeksikan yang menjadikan pembakaran ruang bakar tidak sempurna.

Hidrokarbon merupakan sebuah senyawa yang terdiri dari unsur karbon (C) dan unsur hidrogen (H). Seluruh hidrokarbon memiliki rantai karbon dan atom-atom hidrogen yang berikatan dengan rantai tersebut. Istilah tersebut digunakan juga sebagai pengertian dari hidrokarbon alifatik. Gas metana (gas rawa) adalah hidrokarbon dengan satu atom karbon dan empat atom hidrogen $\mathrm{CH}_{4}$. Etana adalah hidrokarbon yang terdiri dari dua atom karbon bersatu dengan sebuah ikatan tunggal, masing-masing mengikat tiga atom karbon: $\mathrm{C}_{2} \mathrm{H}_{6}$. Propana memiliki tiga atom $\mathrm{C}\left(\mathrm{C}_{3} \mathrm{H}_{8}\right)$ dan seterusnya $\left(\mathrm{C}_{\mathrm{n}} \mathrm{H}_{2 \cdot n+2}\right)$.

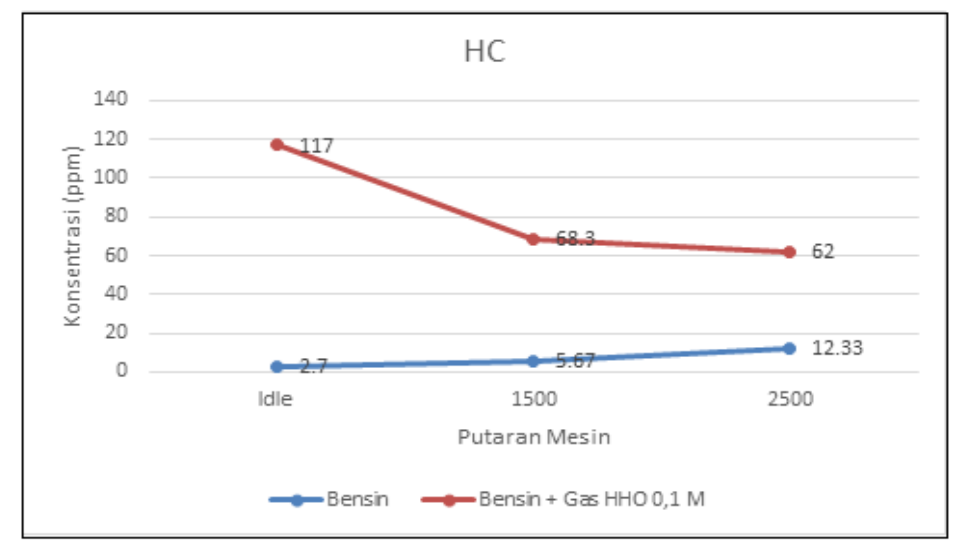

GAMBAR 5. Grafik hasil emisi gas buang hidrokarbon.

Pada gambar 5 menunjukkan hasil gas emisi hidrokarbon dengan bahan bakar bensin pada putaran mesin idle adalah $2.7 \mathrm{ppm}$, putaran mesin $1500 \mathrm{rpm}$ adalah $5.67 \mathrm{ppm}$, dan putaran mesin adalah $2500 \mathrm{rpm}$ adalah $12.33 \mathrm{ppm}$. Penambahan gas HHO 0.1 Mol di dapatkan data tersebut pada putaran mesin idle adalah $111 \mathrm{ppm}$, putaran mesin $1500 \mathrm{rpm}$ adalah 68.3 ppm, dan putaran mesin $2500 \mathrm{rpm}$ adalah $62 \mathrm{ppm}$. Emisi $\mathrm{HC}$ yang tinggi setelah ditambahkan gas HHO 0.1 Mol menunjukan 3 kemungkinan penyebabnya yaitu CC catalytic converter yang tidak berfungsi, AFR yang tidak tepat atau bensin tidak terbakar dengan sempurna di ruang bakar. Apabila catalytic converter bekerja dengan normal tapi HC tetap tinggi, maka hal ini menunjukkan gejala bahwa AFR yang tidak tepat atau terjadi misfire. Untuk mobil yang dilengkapi dengan sistem EFI, gejala misfire ini harus segera diatasi karena apabila didiamkan, ECU akan terus menerus berusaha membuat AFR menjadi fuel-rich-mixture karena membaca bahwa masih ada oksigen yang tidak terbakar. Kendaraan roda 4 yang tidak dilengkapi dengan catalytic converter (CC), emisi HC yang dapat ditolerir adalah $500 \mathrm{ppm}$ dan untuk mobil yang dilengkapi dengan CC, emisi HC yang dapat ditolerir adalah $50 \mathrm{ppm}$. Mesin uji dengan kode 1 NZ-FE telah dilengkapi dengan catalytic converter (CC). Sebelum penambahan gas HHO 0,1 Mol di dapatkan hasil $\mathrm{HC}$ rata-rata yang rendah berada dibawah toleransi dan didapatkan emisi $\mathrm{HC}$ ratarata yang tinggi melebihi toleransi akibat penambahan gas HHO $0.1 \mathrm{Mol}$ melalui filter udara tapi menurut peraturan Menteri Lingkungan Hidup kadar emisi tersebut masih baik karena kadar CO dibawah 1.5\% dan HC dibawah 200 ppm diatas tahun pembuatan tahun 2007 [14].

Karbon dioksida atau zat asam arang adalah sejenis senyawa kimia yang terdiri dari dua atom oksigen dan sebuah atom karbon, berbentuk gas pada keadaan temperatur dan tekanan standar dan merupakan gas rumah kaca yang penting karena ia menyerap gelombang inframerah dengan kuat. Karbon dioksida merupakan komponen penting dalam siklus karbon, dihasilkan dari hasil samping pembakaran bahan bakar fosil. 


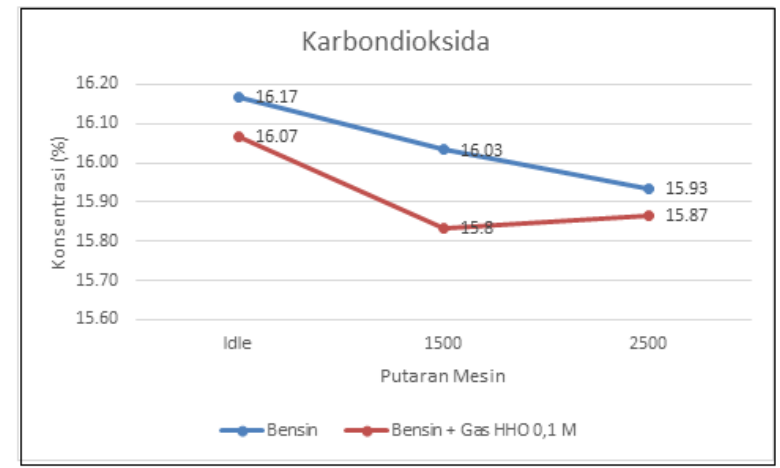

GAMBAR 6. Grafik hasil emisi gas buang karbondioksida.

Pada gambar 6 menunjukkan hasil emisi gas buang karbon dioksida dengan bahan bakar bensin pada putaran mesin idle adalah $16.17 \%$, putaran mesin $1500 \mathrm{rpm}$ adalah $16.03 \%$, dan putaran mesin adalah $2500 \mathrm{rpm}$ adalah 15.93\%. Penambahan gas HHO $0.1 \mathrm{M}$ didapatkan data tersebut pada putaran mesin idle adalah $16.33 \%$, putaran mesin $1500 \mathrm{rpm}$ adalah $16.03 \%$, dan putaran mesin $2500 \mathrm{rpm}$ adalah $15.87 \%$.

Konsentrasi $\mathrm{CO}_{2}$ menunjukkan secara langsung status proses pembakaran di ruang bakar. Semakin tinggi maka semakin baik. Saat AFR berada di angka ideal, emisi $\mathrm{CO}_{2}$ berkisar antara $12 \%$ sampai $15 \%$. Putaran mesin idle emisi $\mathrm{CO}_{2}$ tanpa gas $\mathrm{HHO}$ dan dengan penambahan gas HHO pada putaran mesin idle dan 1500 rpm menunjukkan konsentrasi yang tidak ideal. Konsentrasi ideal emisi $\mathrm{CO}_{2}$ tanpa gas $\mathrm{HHO}$ pada putaran mesin 1500 dan $2500 \mathrm{rpm}$ dan dengan penambahan gas HHO pada putaran mesin $2500 \mathrm{rpm}$. Apabila AFR terlalu sedikit bahan bakar atau terlalu lebih bahan bakar, maka emisi $\mathrm{CO}_{2}$ akan turun secara drastis. Apabila $\mathrm{CO}_{2}$ berada dibawah $12 \%$, maka kita harus melihat emisi lainnya yang menunjukkan apakah AFR fuel-rich-mixture atau fuel-lean-mixture. Perlu diketahui bahwa sumber $\mathrm{CO}_{2}$ ini hanya diruang bakar. Apabila $\mathrm{CO}_{2}$ terlalu rendah tapi $\mathrm{CO}$ dan $\mathrm{HC}$ normal, menunjukkan adanya kebocoran exhaust pipe [7].

Oksigen atau zat asam adalah unsur kimia yang mempunyai lambang $\mathrm{O}$ dan nomor atom 8. Dalam tabel periodik, oksigen merupakan unsur nonlogam golongan VIA (kalkogen) dan dapat dengan mudah bereaksi dengan hampir semua unsur lainnya (utamanya menjadi oksida). Pada temperatur dan tekanan standar, dua atom oksigen berikatan menjadi $\mathrm{O}_{2}$, gas yang tidak berwarna, tidak berasa, dan tidak berbau. Oksigen merupakan unsur paling melimpah ketiga di alam semesta berdasarkan massa setelah hidrogen dan helium.

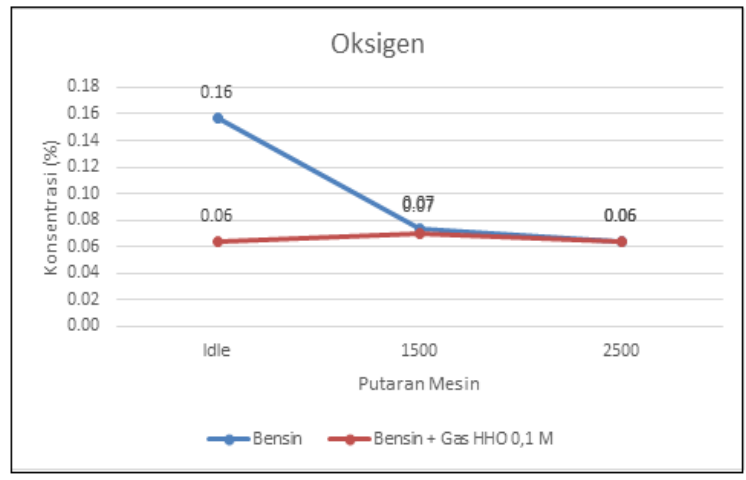

GAMBAR 7. Grafik hasil emisi gas buang oksigen.

Pada gambar 7 menunjukkan hasil emisi gas buang oksigen dengan bahan bakar bensin pada putaran mesin idle adalah $0.16 \%$, putaran mesin $1500 \mathrm{rpm}$ adalah $0.07 \%$, dan putaran mesin adalah $2500 \mathrm{rpm}$ adalah $0.06 \%$. Penambahan gas HHO 0,1 M didapatkan data tersebut pada putaran mesin idle adalah $0.08 \%$, putaran mesin $1500 \mathrm{rpm}$ adalah $0.07 \%$, dan putaran mesin $2500 \mathrm{rpm}$ adalah $0.06 \%$. Konsentrasi oksigen pada emisi gas buang sebelum ditambahkan dan sesudah di tambahkan gas HHO 0.1 Mol menunjukkan nilai yang rendah. Konsentrasi yang rendah berarti semua oksigen dapat terpakai semua dalam 
proses pembakaran dan ini dapat berarti bahwa AFR cenderung pada keadaan campuran bahan bakar berlebih. Dalam kondisi demikian, rendahnya konsentrasi oksigen akan berbarengan dengan tingginya emisi $\mathrm{CO}$. Pada emisi $\mathrm{CO}$ gas buang mesin bensin EFI tipe L tanpa gas HHO nilainya rendah yang berarti pembakaran sempurna dan setelah penambahan gas $\mathrm{HHO}$ konsentrasi $\mathrm{CO}$ naik, menunjukan AFR pada proses pembakaran kelebihan bahan bakar. Konsentrasi oksigen tinggi dapat berarti AFR pada keadaan campuran sedikit bahan bakar tapi juga dapat menunjukkan beberapa hal lain dan tingginya $\mathrm{CO}$ dan $\mathrm{HC}$ bila oksigen terlalu tinggi [2].

\section{Air Fuel Ratio Relative $(\lambda)$}

Terjadinya proses pembakaran di dalam mesin agar dapat menghasilkan tenaga yang optimala maka harus memenuhi 3 persyaratan utama, yaitu tekanan kompresi yang tinggi, waktu pengapian yang tepat serta percikkan bunga api pada busi yang kuat, dan campuran udara serta bahan bakar yang sesuai.

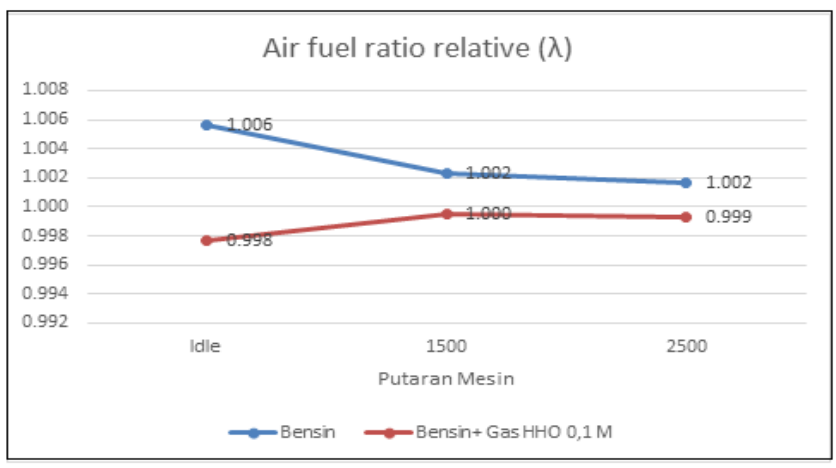

GAMBAR 8. Grafik hasil air fuel ratio relative $(\lambda)$.

Pada gambar 8 menunjukkan hasil air fuel ratio relative $(\lambda)$ bahan bakar bensin pada putaran mesin idle adalah 1.006, putaran mesin $1500 \mathrm{rpm}$ adalah 1.002 dan putaran mesin adalah $2500 \mathrm{rpm}$ adalah 1.002. Penambahan gas HHO 0.1 M didapatkan data tersebut pada putaran mesin idle adalah 0,998 , putaran mesin $1500 \mathrm{rpm}$ adalah 1.000 dan putaran mesin $2500 \mathrm{rpm}$ adalah 0.999. Angka air fuel ratio relative $(\lambda)$ tanpa menggunakan gas HHO putaran mesin idle, $1500 \mathrm{rpm}$, dan $2500 \mathrm{rpm}$ menunjukan stoichiometric mixtures. Penambahan gas HHO 0,1 Mol menunjukan stoichiometric mixtures pada putaran mesin $1500 \mathrm{rpm}$ dan fuel-rich-mixture pada putaran idle dan $2500 \mathrm{rpm}$.

Keadaan pembakaran bisa juga dalam keadaan fuellean mixtures, stoichiometric mixtures, dan fuel-rich mixtures. Keadaan fuellean mixtures adalah rasio antara udara dan bahan bakar tidak seimbang karena campuran bahan bakar sedikit, fuel-rich mixtures adalah rasio antara udara dan bahan bakar tidak seimbang karena campuran bahan bakar berlebih, dan stoichiometric mixtures adalah rasio antara udara dan bahan bakar dalam kondisi sempurna atau tepat ${ }^{`}[10]$.

\section{Analisa dan Pembahasan Konsumsi Bahan bakar}

Mesin pembakaran dalam yang dipakai pada kendaran bermotor mempunyai volume silinder dan jumlah silinder yang berbeda-beda sesuai dengan kegunaan kendaraan itu. Volume selinder menentukan besar kecilnya penggunaan bahan bakar yang dikonsumsinya agar mesin dapat beroperasi dengan baik.

Dalam penelitian ini dilakukan analisa terhadap konsumsi bahan bakar pada saat mesin dioperasikan dengan bahan bakar bensin tanpa tambahan gas HHO dan dengan tambahan gas HHO. Data yang diperoleh ditampilkan dalam bentuk tabel data dan grafik seperti yang ditunjukkan pada gambar 9 .

Konsumsi bahan bakar bensin rata-rata dapat menempuh jarak $9.823 \mathrm{~km} / \mathrm{l}$ tanpa penambahan suplemen bahan bakar gas HHO. Dengan penambahan suplemen bahan bakar gas HHO sebesar 0.1 Mol diperoleh jarak tempuh $9.556 \mathrm{~km} / \mathrm{l}$, lebih kecil daripada mesin tanpa tambahan gas HHO. Hal ini ada kaitannya dengan sistem air fuel rasio yang mungkin 
tidak sesuai dengan campuran bahan bakar dengan udara yang dikendalikan oleh sistem injektor pada mesin tersebut. Sehingga proses pencampuran bahan bakar menuju sempurna tidak tercapai. Dalam penelitian ini menggunakan mesin injeksi tipe L, nampak bahwa konsumsi bahan bakar setelah ditambahkan gas HHO $0.1 \mathrm{Mol}$ menjadi lebih boros $2.8 \%$ daripada tanpa menggunakan gas HHO, hal ini dikarenakan sensor airflow mendeteksi penambahan jumlah udara akibat penambahan gas HHO pada filter udara yang menjadikan AFR membaca jumlah udara yang terhisap terlalu besar atau fuel-rich-mixture. Bahan bakar bensin di injeksikan pada ruang pembakaran tergantung pada sensor airflow yang mendeteksi jumlah udara pada filter udara.

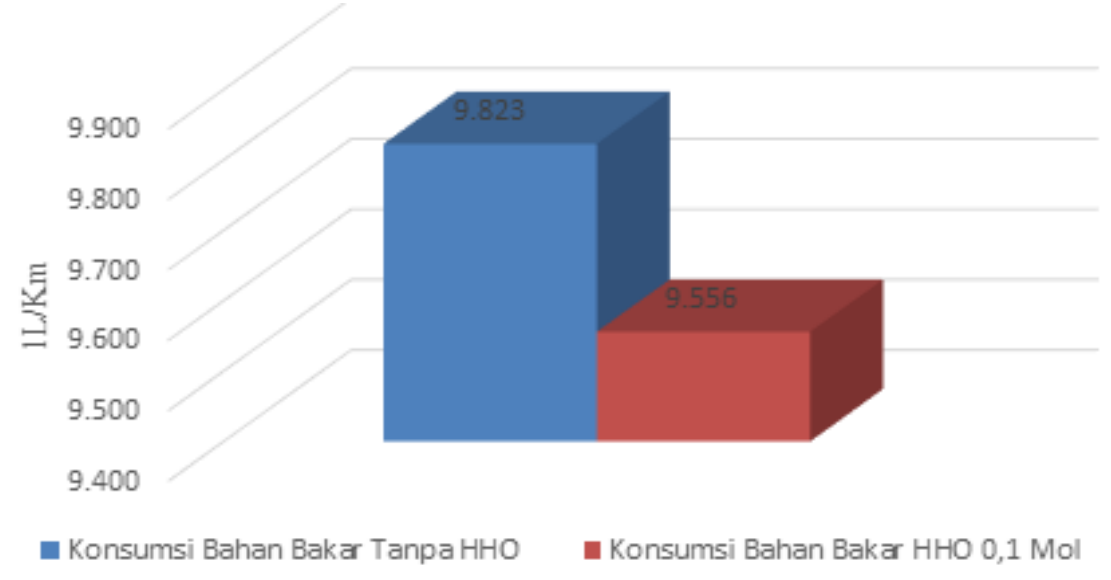

GAMBAR 9. Grafik hasil konsumsi bahan bakar $1 \mathrm{~L} / \mathrm{km}$.

\section{Analisa Pembanding Emisi Gas Buang}

Penelitian ini dilakukan dengan penambahan gas HHO 0.1 Mol mengunakan mesin EFI tipe L, karena belum ada pembanding maka dilakukan analisa perbandingan dari penelitian yang sudah dilakukan dengan mesin EFI tipe D. Penelitian penambahan gas HHO pada mesin EFI tipe D kapasitas silinder $1300 \mathrm{cc}$ seperti yang ditunjukkan pada Tabel 3.

TABEL 3. Emisi gas buang dengan pembanding literatur.

\begin{tabular}{|c|c|c|c|c|c|}
\hline \multirow{2}{*}{$\begin{array}{l}\text { Emisi gas } \\
\text { buang }\end{array}$} & \multicolumn{2}{|c|}{$\begin{array}{l}\text { Analisa hasil pengujian emisi } \\
\text { mesin tipe L 2500rpm }\end{array}$} & \multicolumn{3}{|c|}{$\begin{array}{l}\text { Analisa hasil pengujian emisi mesin tipe D } \\
\text { 3000rpm [4] }\end{array}$} \\
\hline & $\begin{array}{c}\text { Bahan bakar } \\
\text { bensin tanpa } \\
\text { HHO }\end{array}$ & $\begin{array}{c}\text { Bahan bakar } \\
\text { bensin + HHO }\end{array}$ & $\begin{array}{l}\text { Bahan bakar } \\
\text { bensin HHO }\end{array}$ & $\begin{array}{c}\text { Bahan bakar } \\
\text { bensin + HHO }\end{array}$ & $\begin{array}{l}\text { Presentasi } \\
\text { penurunan }\end{array}$ \\
\hline $\mathrm{HC}(\mathrm{ppm})$ & 12.33 & 62 & 86 & 72 & $16.28 \%$ \\
\hline $\mathrm{CO}(\%)$ & 0.00 & 0.01 & 1.11 & 0.94 & 15.31 \\
\hline
\end{tabular}

Sementara penambahan gas HHO pada mesin EFI tipe D kapasitas silinder $1200 \mathrm{cc}$ menunjukkan adanya penurunan kadar emisi $\mathrm{HC} 5.5 \%$ dan $\mathrm{CO} 3.57 \%$ seperti yang ditunjukkan pada Tabel 4. Penurunan emisi gas buang pada mesin bensin EFI tipe D karena prinsip kerja mesin tersebut tidak mengukur jumlah udara tetapi keadaan besarnya tekanan hampa udara pada intake manifold yang menyebabkan injeksi bahan bakar bensin tidak terpengaruh akibat penambahan gas $\mathrm{HHO}$ dan gas HHO tersebut menjadikan pembakaran pada ruang bakar menjadi sempurna.

Pada mesin bensin EFI tipe L terdapat kenaikan pada emisi gas buang karena prinsip kerja mesin tersebut terdapat sensor yang mengukur jumlah udara pada filter udara menuju ruang bakar sebagai penentu banyaknya bahan bakar yang diinjeksikan. Setelah ditambahkan gas HHO pada mesin bensin tipe L sensor mendeteksi adanya penambahan jumlah udara dan bahan bakar yang diinjeksikan pada ruang bakar bertambah berakibat gas HHO tersebut tidak menjadikan pembakaran pada ruang bakar menjadi sempurna. Dari pengukuran terlihat emisi gas buang dengan membandingkan hasil dengan standar mesin bensin dengan kapasitas selinder $1300 \mathrm{cc}$ dapat dilihat pada tabel 3 dan mesin bensin dengan kapasitas selinder $1200 \mathrm{cc}$ dapat dilihat pada tabel 4. 
TABEL 4. Emisi gas buang dengan pembanding literatur.

\begin{tabular}{cccccc}
\hline \multirow{2}{*}{$\begin{array}{c}\text { Emisi gas } \\
\text { buang }\end{array}$} & \multicolumn{2}{c}{$\begin{array}{c}\text { Analisa hasil pengujian emisi } \\
\text { mesin tipe L 2500rpm }\end{array}$} & $\begin{array}{c}\text { Analisa hasil pengujian emisi mesin tipe D } \\
\text { 3000rpm [5] }\end{array}$ \\
\cline { 2 - 6 } & $\begin{array}{c}\text { Bahan bakar } \\
\text { bensin tanpa } \\
\text { HHO }\end{array}$ & $\begin{array}{c}\text { Bahan bakar } \\
\text { bensin + HHO }\end{array}$ & $\begin{array}{c}\text { Bahan bakar } \\
\text { bensin HHO }\end{array}$ & $\begin{array}{c}\text { Bahan bakar } \\
\text { bensin + HHO }\end{array}$ & $\begin{array}{c}\text { Presentasi } \\
\text { penurunan }\end{array}$ \\
\hline HC (ppm) & 12.33 & 62 & 237.5 & 225 & $5.55 \%$ \\
CO (\%) & 0.00 & 0.01 & 2.9 & 2.8 & $3.57 \%$ \\
\hline
\end{tabular}

\section{KESIMPULAN}

Penambahan gas HHO 0.1 Mol pada mesin bensin EFI tipe L melalui filter udara pada proses pembakaran meningkatkan kadar emisi gas karbondioksida, hidrokarbon, karbonmonoksida, oksigen, dan angka air fuel ratio menunjukan campuran bahan bakar berlebih. Meningkatknya kadar emisi gas buang karena prinsip kerja mesin EFI tipe L setelah penambahan gas HHO 0.1 Mol menyebabkan sistem EFI tipe L mengalami kesalahan fungsi yang berakibat pembakaran di ruang bakar kelebihan bahan bakar dan campuran gas HHO dan bahan bakar bensin tersebut tidak dapat terbakar dengan sempurna pada proses pembakaran motor bakar. Konsumsi bahan bakar rata-rata akibat penambahan gas HHO lebih boros $2.8 \%$ karena rasio AFR dalam keadaan fuel rich mixture. Rasio AFR dalam keadaan fuel rich mixture karena prinsip kerja mesin EFI tipe L mengalami kesalahan fungsi setelah penambahan gas HHO 0.1 Mol pada filter udara menyebabkan bahan bakar yang diinjeksikan di ruang bakar kelebihan bahan bakar.

\section{UCAPAN TERIMA KASIH}

Saya mengucapkan banyak terima kasih kepada penanggungjawab laboratorium Teknik Fisika, Fakultas Teknik dan Sains, Universitas Nasional, yang telah memberikan ijin melakukan penelitian ini. Kepada para teknisi dan beberapa orang yang telah membantu selesainya penelitian ini yang tentunya selalu mendukung dan selalu memberi arahan pada penelitian ini.

\section{DAFTAR PUSTAKA}

[1] Sulistyono, 2012, "Pemanasan global (Global Warming) dan hubungannya dengan penggunaan bahan bakar fosil," Forum Teknologi, Vol. 02, No. 2.

[2] Iqbal Wahyudzin dan Harus Laksana Guntur, 2012, "Studi karakteristik generator hho dry cell dan aplikasinya pada kendaraan bermesin injeksi 1300," TEKNIK POMITS, Vol. 1, pp. 1-6.

[3] Yasin Karagöz, Emre Orak, Levent Yüksek, Tarkan Sandalc1, 2015 "Effect of hydrogen addition on exhaust emissions and performance of a spark ignition engine," Environmental Engineering and Management Journal, Vol. 14, pp. 665-672.

[4] Raharjo, Winarno Dwi, dan Karnowo, Mesin konversi Energi, Semarang: Unnes Press, 2008.

[5] Setiawan, Andry, "Motor bakar," 2011 April 2012. [Online]. Available: http://menujubiru.wordpress.com/. [Accessed 1 Juni 2017].

[6] Ruswid, "Electronic fuel injection EFI," 2008. [Online]. Available: https://rus28.files.wordpress.com/2011/11/efi modul1.pdf. [Accessed 10 Juni 2017].

[7] Rengkord Riders, 2012, "Pengertian uji emisi terhadap mesin,". [Online]. Available: https://rengkodriders.wordpress.com/2012/05/08/pengertian-uji-emisi-terhadapmesin/.

[8] Chaisermtawan P, Jarungthammachote S, Chuepeng S and Kiatiwat T, 2012 "Gaseous emissions and combustion efficiency analysis of hydrogen-diesel dual fuel engine under fuel-lean," American Journal of Applied Sciences, Vol. 9 (11), pp. 
1813-1817.

[9] Abdul Hamid, Ari Santoso, 2006 "Kontrol air fuel ratio pada spark ignition engine sistem efi sekuensial menggunakan kontrol fuzzy adaptif dapat menekan beaya operasional kendaraan," Prosiding Seminar Nasional Manajemen Teknologi III.

[10] Chakrapani K dan Neelamegam P, 2011 "Optimization of fuel consumption using HHO in HDL," Theo and Infor tech 31 (2).

[11] Yanur D. S. K., Arzaqa Ghiffari, 2013, "Studi karakteristik generator gas HHO," TEKNIK POMITS, Vol. 1, pp. 1-6.

[12] Laksono, Endang Widjayanti, 2005 Pengaruh katalisator terhadap laju reaksi, Yogyakarta.

[13] Fahmi Wirawan, Djoko Sungkono Kawano, 2014, "Pengaruh penambahan gas HHO terhadap unjuk kerja mesin diesel putaran konstan dengan variasi massa katalis KOH pada generator gas HHO," TEKNIK POMIT, Vol. 1, pp. 1-6.

[14] Menteri Negara Lingkungan Hidup, 2006, "Peraturan menteri ambang batas emisi gas buang No. 5,".

[15] Ena Marlina, 2016, "Pengaruh variasi larutan elektrolit terhadap produksi brown gas," INFO TEKNIK, Vol. 17, No. 2, pp. 187-196. 